\title{
はり構造のモ一ド形状に基づく複数損傷の検出感度に関する検討
}

\author{
荒川亮 ${ }^{* 1}$ ，啮谷嗣 ${ }^{* 1}$
}

\section{Sensitivity of Detection of Multiple Damages Using Mode Shape of Beam Structures}

\author{
Ryo ARAKAWA ${ }^{* 2}$ and Yotsugi SHIBUYA \\ $*^{2}$ Department of Mechanical Engineering, Akita University \\ 1-1 Tegata Gakuen-machi Akita-shi, Akita, 010-8502 Japan
}

\begin{abstract}
Sensitivity of damage detection for beam structures with multiple damages is discussed. Mode shape of beam structures is estimated by strain response. The influence of damage on mode shape is shown by comparison between damaged beam and intact beam. Damages are detected from the mode shape. To detect position of the damage, continuous wavelet transform is applied to the difference in the mode shape. A peak of the wavelet transform become high with the increase of the damage level.
\end{abstract}

Key Words : Damage Evaluation, Mode Shape, Impulse Response, Health Monitoring

\section{1. 緒雷}

航空機や機械構造物において，損傷を早期に検 出し，構造の健全性を評価するためのへルスモニ タリングが重要である. 構造の広い領域を対象と する場合，振動応答によるへルスモニタリングが 有効である(1).

本研究では，振動乇一ド形状が構造のひずみ応答か ら推定できることに着目し，モード形状に基づいた損 傷検出の感度に関する検討を行った. 複数の損傷を有 するはりのモード形状を衝撃応答解析により推定した. 損傷検出は推定したモード形状に基づいて行い，損傷 の程度を変えて検出感度を確認した。

\section{2. モ一ド形状計測}

損傷を有するはり構造のモード形状を推定するため に，領域分割した片持はりを考える. 図 1 は分布荷重 $p(x, t)$ を受ける複数の損傷を有するはりのモデルを示 している. 解析には中立軸を $x$ とする $x-z$ 座標系を用 いる.はりは, 長さを $l$, 幅を $h$ とする. 損傷領域は隣 の領域と岡性を変えることで，損傷状態を模擬するも のとする. 領域の境界は $l_{j}(j=1 \sim N-1)$ とする. 固定端 から $j$ 番目の領域の運動方程式を次のように表すこと ができる。

$\rho_{j} A_{j} \frac{\partial^{2} w_{j}}{\partial t^{2}}+E_{j} I_{j} \frac{\partial^{4} w_{j}}{\partial x^{4}}+R_{j} \frac{\partial^{5} w_{j}}{\partial x^{4} \partial t}+S_{j} \frac{\partial w_{j}}{\partial t}=p(x, t)$,

$$
\left(l_{j-1}<x<l_{j}\right)
$$

ただし，Eは縦弾性係数，Iは断面二次モーメント， $\rho$ は質量密度, $A$ は断面積， $t$ は時間である.また，はり の $z$ 方向のたわみを $w$ とする. ここで, 下付き添え字

${ }^{* 1}$ 正員, 秋田大学大学院工学資源学研究科 ( $\bar{T} 010-8502$ 秋 田県秋田市手形学園町 1-1)

E-mail: d9508005@wm.akita-u.ac.jp $j$ は固定端から $j$ 番目の領域を表している.また， $R$ は 内部減衰倸数, $S$ は外部减衰俰数である.

衝撃集中荷重 $p(x, t)$ がはりの位置 $x_{p}$ に作用するもの として, 式で表すと次のようになる.

$$
p(x, t)=p_{0} \delta(t) \delta\left(x-x_{p}\right)
$$

ただし， $p_{0}$ は集中荷重の強さ， $\delta()$ はirac のデルタ関 数である. 集中荷重に対して, 時間に関してフーリエ 変換し, 座標 $x$ にいてフーリエ級数展開する. 式(1) のフーリエ変換は次のように得られる.

$$
\begin{array}{r}
\left(\eta_{j}+i r_{j} \omega\right) \frac{\partial^{4} w_{j}^{*}}{\partial x^{4}}-\left(\beta_{j}^{2} \omega^{2}-i s_{j} \omega\right) w_{j}^{*} \\
=2 q_{0} \sum_{n=1}^{\infty} \sin \frac{n \pi x_{p}}{l} \sin \frac{n \pi x}{l}, \\
\left(l_{j-1}<x<l_{j}\right)
\end{array}
$$

ここで, $w^{*}$ はフーリエ変換されたはりのたわみを 示している.ただし，次のような無次元パラメー タを用いている.

$$
\left.\begin{array}{l}
r_{j}=\frac{R_{j}}{E I}, \quad s_{j}=\frac{S_{j}}{E I}, \quad \eta_{j}=\frac{E_{j} I_{j}}{E I}, \\
\beta_{j}^{2}=\frac{\rho_{j} A_{j}}{E I}, \quad q_{0}=\frac{p_{0}}{E I}
\end{array}\right\}
$$

また, $j$ 番目の領域の損傷の程度をパラメータ $\kappa_{j}$

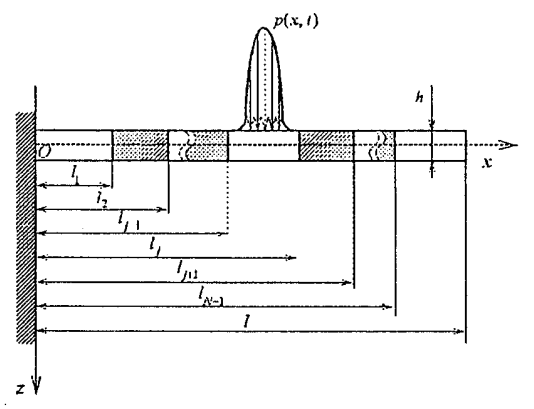

Fig. 1 A uniform beam subjected to distributed load $p(x, t)$

日本機械学会 [No.10-9] M\&M2010材料力学カンファレンス CD-ROM論文集 [2010.10.9-11,長岡] 
として次のように定義する.

$$
\kappa_{j}=\frac{\left(l_{j}-l_{j-1}\right) / l}{\eta_{j}}
$$

片持はりの両端における境界条件と, 領域の境界に おける連続性を考慮し，はり表面 $z=h / 2$ における垂直 ひずみ $\varepsilon_{x}$ のフーリエ変換 $\varepsilon_{x}^{*}(x, \omega)$ を導くことができる. 衝撃荷重の位置を変えてひずみ応答のフーリエ変換を 求め, 一次共振における值を得ることで, はりの 一次振動モード形状を推定する(2).

数值計算において，2 個の損傷を有するはりを 考える. 2 個の損傷を有するはりは, 領域分割を $N$ $=5$ とし, 固定端から 2 番目と 4 番目の領域に損傷 があるものとする.ひずみ応答から推定した損傷 を有するはりのモード形状を図 2 に示す. 縦軸 $U$ はモード形状を自由端 $x=l$ における值で正規化し て, 次のように表す。

$$
U=\left|\varepsilon_{x}^{*}(x, \omega)\right| /\left|\varepsilon_{x}^{*}(l, \omega)\right|
$$

ここで，自由端における值はモード形状を滑らか に外挿することで求めた，図中において，奏線は 損傷がないはり，破線は 2 番目の領域にある損傷 の中心を $d_{2} / l=0.25,4$ 番目の領域にある損傷の中 心を $d_{4} / l=0.5$ としたものである.また，それらの 損傷の程度を $\kappa_{2}=\kappa_{4}=0.36$ とした. 図より，損傷 を有するはりのモード形状には損傷による変化が 現れていることがわかる。

\section{3. 位置検出}

損傷がモード形状に与える影響から損傷による 特徵を抽出する. モード形状の差 $\xi(x)$ を次のよう に表す。

$$
\xi(x)=U_{d}(x)-U_{h}(x)
$$

ここで, $U_{d}$ は損傷があるはりのモード形状， $U_{h}$ は 損傷のないはりのモード形状である.モード形状 の差 $\xi(x)$ に関して, 連続ウェーブレット変換を求 めることで損傷の同定を行う．ウェーブレット変 換において，端の不連続性の影響を考慮して，モ 一ド形状の差 $\xi(x)$ の両端から外側に関して, 滑ら かに外挿した. 本研究では 4 次の Gaussian マザー。 ウェーブレットを採用する(2).

図 3 は, 図 2 に破線で示した 2 個の損傷を有す るはりについて，モード形状の差 $\xi(x)$ を求め，ウ エーブレット変換したものである．損傷の位置に 下に凸のピークが現れている。

次に, 損傷の程度とウェーブレット変換の下に 凸のピーク值との関係を調べる. 図 4 は損傷を有 するはりに関して，2 番目の領域の損傷の程度 $\kappa_{2}$

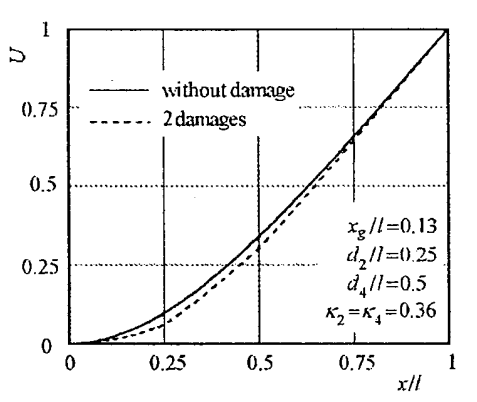

Fig. 2 Mode shape of beams with damages and without damage

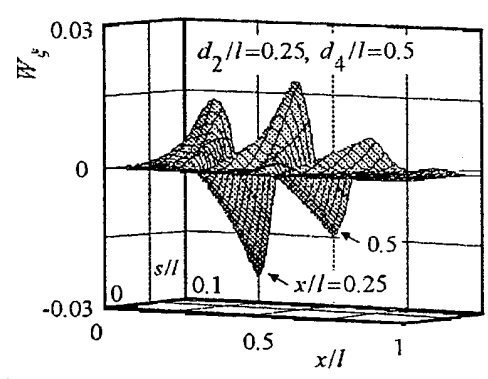

Fig. 3 Wavelet transform of first mode shape of the beam with damage at $d_{2} / l=0.25, d_{4} / l=0.5$

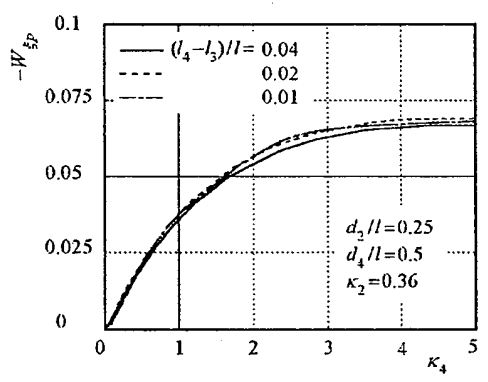

Fig. 4 Sensitivity of damage detection

を 0.36 とし, 4 番目の領域の損傷の程度を变えて 示したウェーブレット変換のピーク値の結果であ る. 縦軸はその損傷位置に現れたウェーブレット 変換のピーク值 $W_{\xi}$ である. 図でその損傷の長さ $\left(l_{4}-l_{3}\right) / l$ を変えて表しており, 実線は $\left(l_{4}-l_{3}\right) / l=$ 0.04 , 破線は 0.02 , 一点鎖線は 0.01 とした結果で ある. 図より, 損傷の程度のパラメータ $\kappa_{4}$ が大き くなると，ピーク值も大きくなっていることがわ かる. また，いずれの損傷の長さでも同様の傾向 を示しており，長さ, 剛性によらず, パラメータ $\kappa_{j}$ で $j$ 番目の領域の損傷の程度を表現できると考 えられる。

\section{文献}

(1) Rucka, M. and Wilde, K., J. Sound Vibr., Vol.297, (2006), pp.536-550.

（2）荒川，渋谷，機論，75A, (2008), pp.142-147. 